\title{
The Successful Teacher's Verbal Cues in View of Interpersonal Communication to Lead EFL Adult Beginner Learner's Accuracy in Calling Interaction
}

\author{
Nurul Hatifah \\ nhatifah@gmail.com \\ State University of Makassar, Indonesia
}

\begin{abstract}
The objectives of the research are to give descriptive account of (1) the successful teacher's verbal cues leading the adult beginner learner's accuracy via calling interaction and (2) the learner's perception of the teacher's verbal cues leading her accuracy. This research applied descriptive qualitative research. By using purposive sampling technique, one teacher and one adult learner of White House Indonesia, English institution, were chosen as the research objects. The data regarding with teacher's verbal cues in view of interpersonal communication used in calling interaction were collected by recording voice by using Voice Call Recorder, and semi-structured interview obtained the data regarding with the learner's perception of the teacher's verbal cues. The results revealed that (1) verbal indirect cue covering recalling cue, clarifying cue, associating cue and exemplifying cue, and verbal direct cue covering recalling cue and clarifying cue were the typically successful verbal cues used by the teacher to lead the adult beginner learner's accuracy. (2) The teacher's verbal cues were helpful to lead the learner's accuracy in term of pronunciation, vocabulary, and grammar in calling interaction. Therefore, it can be concluded that the teacher's verbal cues could facilitate the learners to respond the teacher's questions accurately since the teacher and learners were involved in interpersonal communication.
\end{abstract}

Keywords: Verbal cues, interpersonal communication, English accuracy.

\section{INTRODUCTION}

Teaching is communicating the form of knowledge, skill, and attitudes to students which generates shared meaning and accomplishes academic and social goals (Rasyid, 2015). To conduct it, its process must involve dyadic doer of communication, they are teacher and learners. They work in face to face and telephonic interaction (calling interaction). Especially in calling interaction which is the focus of the research, its learning process is undertaken by learners who have accomplished the Face to Face program in White House, the English institution in Makassar, Indonesia. It is considered as reinforcement program for learners because the materials discussed are related to previous experience gained in Face to Face program, the first program for learners.

Teaching and learning process in calling interaction automatically has obstacles covering mobile signal, credit, disagreed time of communication doer (teacher and learners), learners' speaking skill, and so on. Based on the preliminary observation, the learner's obstacle is accuracy in responding the teacher's questions. The learners often respond the teacher's question inaccurately. 
Therefore, dealing this problem, the researcher intended to investigate the teacher's verbal cues in view of interpersonal communication to lead learner's accuracy covering vocabulary, pronunciation, and grammar.

Teacher's cues are to help learners to construct their thought to respond in teaching and learning process. When learners get stuck on the task, the teacher should give cues to lead them rather than telling the answer directly. In calling interaction, the teacher's verbal cues play an important role. Additionally, this interaction comes into view of interpersonal communication to dyadic doer of communication which are learners and teacher. Therefore, the way the teacher cues the learner's inaccurate response of question addressed in view of interpersonal communication was very important to research in order that communication in calling interaction between teacher and learners can be sustainable and can reinforce their pronunciation, vocabulary, and grammar. Additionally, this interaction provides the teacher and learners with a new experience in teaching and learning process. Undeniable fact, ambiguous perception between them might occur, so, in consequence, this study has urgency to be conducted. Since the existence of cuing in calling interaction, the reasons and all the available needs required such as the willingness of the teacher and learner as the participants becomes this study feasible to be conducted.

Some researchers have conducted the teacher's verbal cues in learning process, like Landin's research (1994) about the role of verbal cues in skill learning. The researcher herself chose teacher's verbal cues in view of interpersonal communication to lead the learner's accuracy. Furthermore, this study investigated the teacher's verbal cues focusing on calling interaction, indisputably interpersonal communication must exist. This is what makes it so different. In addition, it revealed whether teacher's verbal cues impacted successfully on learner's accuracy or not. Therefore, the researcher believes that it is a novel idea to conduct this research.

In line with background above, the research questions were put forward as in the following (1) What successful verbal cue does the teacher use to lead the adult beginner learner's accuracy via calling interaction? and (2) What is the learner's perception of the teacher's verbal cues leading her English accuracy? Dealing with the research questions, the objectives of this research were to give descriptive account of (1) the successful teacher's verbal cue leading the adult beginner learner's accuracy via calling interaction and (2) the learner's perception of the teacher's verbal cues leading her English accuracy.

\section{LITERATURE REVIEW}

\section{Verbal Cue}

Northwestern Illinois Association defines cue as an action intended to encourage a student to initiate or continue a task he or she has previously performed. Provide cues for skills that the student has been working on but has not yet reached the proficiency stage. Henkel (2002), a teacher's overall instructional effectiveness depends heavily on how that teacher uses instructional cues. A cue consists of a word, phrase, or sentence that describes a particular aspect of a concept or skill.

\section{Interpersonal Communication}


According to Rasyid (2015:54), interpersonal communication is the communication between two or more to interact each other for sharing the meaning, feeling, knowledge which comprised social context which frames communicators, social identity, social perception, codes and using codes, and purposes/goals.

\section{The characteristic of Adult Beginner Learners}

Jones (2007) attributed adult beginner learners who are:

a. more likely to be motivated and attentive;

b. more likely to build a rapport with their teacher and each other;

c. more likely to have well-defined expectations for their teacher, their course and its style, and their success;

d. less likely to easily grasp new language introduced and have less language awareness;

e. less likely to cause disciplinary problems.

\section{METHOD}

\section{Design and Samples}

This research applied a descriptive research design which collected, analyzed, and interpreted a variety of the data to have information the verbal cues successfully used by the teacher to lead the adult beginner learner's accuracy in calling interaction and the learner's perception of the teacher's verbal cues. The participants of the research were one teacher and one learner. The teacher was chosen because of her competence and working experience almost two years to teach learners in calling interaction. The learner was adult from beginner level. She was purposively taken since she had accomplished her Face to Face program.

\section{Instruments and Procedures}

The researcher applied two kinds of instruments to facilitate this research. Those instruments are:

\section{Voice Call Recorder}

Voice Call Recorder is to answer the research question number 1 (What successful verbal cue does the teacher use to lead the adult beginner learner's accuracy via calling interaction?). The Voice Call Recorder obtained the data in calling interaction between teacher and learner. The process of interaction investigated the teacher's verbal cues and learner's response.

\section{Interview}

Semi-structured interview was used in this research to get data. In applying this type, the researcher provided some questions to ask, but remain flexible so that other information still arose. It is to answer the research question number 2 (What is the learner's perception of the teacher's verbal cues leading her English accuracy?). Semi structured interview guided the researcher to investigate the learner's view of teacher's verbal cues.

In order to collect the data, the researcher conducted the following procedure:

1. The researcher provided the letter permission to White House.

2. The teacher called learners by instructing the teacher to record conversation by using Voice Call Recorder during interaction. The maximum duration is 20-30 minutes per call. The teacher started calling the adult beginner learner on April 25, 2016 at 7:30 pm for thirty-four minutes, the second calling on May 10, 2016 at 7:45 pm for twenty- 
four minutes, and the third calling on May 11, 2016 at 8:00 pm for twenty-five minutes.

3. The teacher started the lesson by greeting.

4. The teacher introduced the topic. The topic of every calling is illustrated as follows:

Table 1: The Topic Discussed in Calling Interaction

\begin{tabular}{|c|c|c|}
\hline CALL & TOPIC & ITEM \\
\hline Call 1 & Personal Information & $\begin{array}{l}\text { 1. Personal Facts (name, age, } \\
\text { hometown, address, } \\
\text { occupation, marital status, } \\
\text { family, etc). } \\
\text { 2. Hobbies } \\
\text { 3. Like and Dislike }\end{array}$ \\
\hline Call 2 & Activities & $\begin{array}{l}\text { 1. Routine } \\
\text { 2. Habits } \\
\text { 3. Action in Progress }\end{array}$ \\
\hline Call 3 & People, Place, and Things & $\begin{array}{l}\text { 1. People's physical look and } \\
\text { personality } \\
\text { 2. Favourite place } \\
\text { 3. Things }\end{array}$ \\
\hline
\end{tabular}

5. In learning process, the teacher provided question for learner related to the topic discussed.

6. Learner responded to teacher's question. Learner's response might be accurate and inaccurate. The inaccurate response analyzed in pronunciation focuses on consonant and vowel sounds, vocabulary is restricted on choosing the appropriate meaning of the words, the different grammatical form of a word, and diction displacement, and grammar concentrates on subject-verb agreement.

7. Teacher's cues were conveyed to learner's inaccurate response to achieve the learner's uptake. The learner's uptake could be successful repair or inaccurate response repair (need repair). The next cues of learner's inaccurate response repair might practically exist or be ignored by the teacher.

8. After learning, semi-structured interview was conducted to the learner. The researcher interviewed the adult beginner learner on May 19, 2016.

\section{Data Analysis}

After conducting all procedures of collecting data, the researcher analyzed the data. According to Miles and Huberman (1984) in Emzir (2012:129-136), some steps in analyzing the data can be seen as follows:

\section{Data collection}

This research covers teacher's verbal cues and learner's response and learner's perception of the teacher's verbal cues as data. Teacher's verbal cues and learner's response were collected through Voice Call Recorder in process calling interaction. Meanwhile the learner's perception of teacher's verbal cues was collected through interview.

2.Data reduction 
This step involves transcribing data, selecting related data, and analyzing the data referring to the research questions.

3.Data display

In this step, the data reduced gave description and analysis of qualitative data about teacher's verbal cues, learner's response and learner's perception of teacher's verbal cues.

4.Conclusion

As the last step, the researcher interpreted and elaborated the data according to the some pertinent ideas as the reference of this research.

\section{RESULT AND DISCUSSIONS}

The findings presents the successful teacher's verbal cue in view of interpersonal communication leading the adult beginner learner's accuracy via calling interaction and the learner's perception of the teacher's verbal cues leading her accuracy.

Research Question 1: What successful verbal cue does the teacher use to lead the adult beginner learner's accuracy via calling interaction?

The teacher's verbal cues were the result of data analysis obtained through Voice Call Recorder in process calling interaction. The successful verbal cues used by the teacher to lead the adult learner's accuracy in term of pronunciation, vocabulary, and grammar were verbal indirect and verbal direct cue. Verbal indirect cue covers recalling, clarifying, associating, and exemplifying cue; whereas, verbal direct cue comprises recalling and clarifying cue. The table below displays the successful teacher's verbal cue.

Table 2. Types of Successful Verbal Cues to Lead the Adult Beginner Learner's Accuracy

\begin{tabular}{|c|c|c|c|c|c|}
\hline \multicolumn{2}{|c|}{ Succesful Verbal Cues } & \multirow{2}{*}{ Element of English } & \multicolumn{3}{|c|}{$\begin{array}{c}\text { Frequency per } \\
\text { call }\end{array}$} \\
\hline Types & Name & & $\begin{array}{c}\text { Call } \\
1\end{array}$ & $\begin{array}{c}\text { Call } \\
2\end{array}$ & $\begin{array}{c}\text { Call } \\
3\end{array}$ \\
\hline \multirow[t]{5}{*}{ Indirect } & Recalling cue & Grammar & & 2 & \\
\hline & & Pronunciation & & & 1 \\
\hline & Clarifying Cue & Grammar & 1 & & \\
\hline & Associating Cue & Vocabulary & & & 1 \\
\hline & Exemplifying Cue & Vocabulary & & & 1 \\
\hline \multirow[t]{2}{*}{ Direct } & Clarifying Cue & Vocabulary & & & 1 \\
\hline & Recalling cue & Grammar & 1 & & \\
\hline
\end{tabular}

According to the table above, the researcher defines these cues according to the types, indirect and direct cue. Based on Texas Education Agency (2011), verbal indirect cue is when the teacher provides a single piece of oral information to indirectly help students 
focus on specific details. Meanwhile, verbal direct cue is when the teacher provides a single piece of oral information to directly help the students focus on specific details. Therefore, the researcher displays the definition of cues found in this research based on this category.

1. Indirect recalling cue is a pointer uttered to remind the learner the material learnt before without telling the verbal redirection, so that direct recalling cue is a pointer uttered to remind the learner the material learnt before by telling the specific error.

\section{Extract 22}

$\mathrm{T} \quad$ : Ingat, lagi lagi. (Remember, once more)

L : Oh yaya, tambah 's'? (Oh yes, plus 's'?)

$\mathrm{T} \quad$ : Yes. tambah 's'(Yes, plus 's')

L : He works?

$\mathrm{T} \quad$ : Yes. He works

Indirect Recalling Cue, Grammar, $2^{\text {nd }}$ Calling, May 10, 2016

\section{Extract 12}

$\mathrm{T}$ : 'She' tadi, ingat 'dia tidak', berarti 'she.., , bukan 'she don't' tapi? ('She' remember, not 'she don't' but?)

L : Oh 'doesn't'.

Direct Recalling Cue, Grammar, $1^{\text {st }}$ Calling, April 25, 2016

2. Indirect clarifying cue is a pointer uttered to make target language less confused and more comprehensible by providing a single piece of oral information indirectly, whereas direct clarifying cue is a pointer uttered to make target language less confused and more comprehensible by telling the error directly.

Extract 11

T : Kalau 'don't' itu untuk 'I, I don't, you don't, they don't, we don't' Kalau 'she/he/it'?

('don't' is for I, 'I don't, you don't, they don't, we don't', what about 'she/he/it'?)

L : Jadi she doesn't?

$\mathrm{T}$ : Yes, that's what I mean. So?

L : She doesn't...

Indirect Clarifying Cue,Grammar, $1^{\text {st }}$ Calling, April 25, 2016

Extract 29

T : So we cannot say 'his tall' 'tingginya', kita tidak bisa mengatakan

itu. Jadi kata bendanya, biasanya ada kalau kita mengisi formulir.

(We cannot say 'his tall', we have to use its noun, usually we find it if we fill form)

L : Height?

Direct Clarifying Cue, Vocabulary, 3rd Calling, May 11, 2016

3. Indirect associating cue is the pointer uttered to lead learner's accuracy by connecting the target language with something else.

Extract 27 
T : So we cannot say 'his tall' 'tingginya', kita tidak bisa mengatakan itu. Jadi kata bendanya, biasanya ada kalau kita mengisi formulir.

(We cannot say 'his tall', we have to use its noun. usually we find it if we fill form)

L : Height?

$\mathrm{T}$ : Yes. seperti itu. Jadi 'his...?

$\mathrm{L} \quad$ : His height...

Vocabulary, 3rd Calling, May 11, 2016

4. Indirect exemplifying cue is the pointer uttered to lead learner's accuracy by illustrating a typical example.

Extract 28

T : No, 'I' itu 'saya', kalaukepunyaan?

(No, 'I' means 'saya' (Indonesian), what is its possessive adjective?)

$\mathrm{L} \quad: \mathrm{Hmm}$

T : Tinggiku? Like I say, mama $k u$, my mother. ('My height', like I say, mama $k u$ (Indonesian), my mother. )

L : Oh my height.

$\mathrm{T}$ : Yes.

Vocabulary, 3rd Calling, May 11, 2016

Teacher's verbal cues in view of interpersonal communication play an important role to lead the adult beginner learner's accuracy via calling interaction. The component of interpersonal communication by Rasyid (2015:45) namely social context which deals with social structure (social norm, rules, and relationship) and social environment (physical and social), communicators, social identity which covers personality, selfconcept, and roles, social perception, codes and using codes, and purposes/goals guided the researcher to review teacher's verbal cues and learner's responses in view of interpersonal communication.

In view of social context which is social norm of Indonesian, the teacher called the learner by using 'ibu/bu'. This appellation is used since the learner is female and older than the teacher. Meanwhile, the learner called the teacher by using teacher's first name or 'de'. According to Rayid (2015:46), it is very impolite and breaks the culture norms if the students address their teacher by first name only. Thus, it implies that the adult learner was impolite in giving honorific to the teacher. Nevertheless, 'de' shows respectful and affection to the younger person. Therefore, the researcher remarks that these appellations are considered to make the dyadic doer of communication (teacher and learner) convenient and bind the intimacy, although calling the teacher's first name cannot bind the cultural norms as the politeness. Additionally, social relationship between teacher and learner in calling interaction showed closeness regarding that the interaction is the continual program of Face to Face program. It is relevant to Jones (2007) that adult beginner learners more likely build a rapport with teacher.

Unfortunately, self-deprecating is also found in adult learner's personality. Selfdeprecating is caused by disapproval of something done. The extract below describes how the adult learner censured herself after obtaining cues by teacher many times. The learner apologized before stating her self-deprecating statement.

According to this finding, the researcher concludes that cueing the same error regularly can make the learner reprehensible, moreover desperate. 
Extract 9

L : Oh 'doesn't'.

$\mathrm{T}$ : Okay.

L : Sorry, sorry, 'she doesn't'

$\mathrm{T}$ : She doesn't like burger.

L : Yes. Sorry M (teacher's initial name). I'm forget.

$\mathrm{T}$ : It's okay.

L : Sedikit sedikit lupa, ingat, lupa lagi. Nanti dibilang apa mi ini sudah diajar lupa lagi (Laughing) (I always forget, remember, forget again. You are probably sick of me because you've already taught me but I always forget)

$I^{\text {st }}$ Calling, April 25, 2016

Research Question 2: What is the learner's perception of the teacher's verbal cues leading her English accuracy?

Learner's perception data was collected through interview session. Based on the interview results, the adult learner found herself facilitated in responding the teacher's question since the teacher's verbal cues were helpful to lead the learner's accuracy in term of pronunciation, vocabulary, and grammar in calling interaction.

- Is the teacher's verbal cues facilitated?

Based on the learner's opinion and experience in calling interaction, the teacher's verbal cues facilitated the learner to repair her inaccurate response.

Extract 45

$\mathrm{T}$ : Biasanya kalau ibu menjawab pertanyaan guru kurang tepat biasanya kan guru tidak langsung kasi jawaban yang benar tapi kasi clue clue supaya ibu bisa jawab pertanyaan dengan tepat.

(Sometimes when you answered the teacher's question inaccurately, the teacher did no directly tell the accurate answer but gave you cues to answer the question accurately)

L :Iya. (Yes)

$\mathrm{T}$ : Nah itu clue clue guru membantu nda bu?

(Well, did the cues help you to answer the question accurately?)

L : Membantu yah karena kadang dilupa jadi kalau dikasi lagi clue clue biasa langsung mi ingat, kan sudah ji dipelajari sebelumnya toh.

(Yes, they did, because sometimes I forget. When the teacher cued me, I directly remembered regarding that the materials had been learnt before)

Adult Learner, May 19, 2016

Related to the extract above, the learner was facilitated by the teacher's verbal cues. Teacher's verbal cues triggered the learner to recall the material given in the Face to Face session. Moreover, her self-confidence in responding the teacher's question occurred powerfully since she considered that the teacher's verbal cues would guide her if she made mistakes as clarified into extract below. 
$\mathrm{T} \quad$ : ...Kalau masih kebiasaan atau rutinitas, kata kerjanya ada ditambahkan dibelakangnya, masih ingat?(... If we are talking about habit or routine, there is something added behind verb, do you still remember?)

L : Pake's'?(Plus 's')

$\mathrm{T}$ : Yes.

L : (Laughing) Oh jadi kayak 'he goes'? (Oh, it's like 'he goes'?)

$\mathrm{T} \quad$ : Iya kayak gitu. (Yes, it is)

Adult learner, Grammar, $2^{\text {nd }}$ Calling, May 10, 2016

- Do teacher's verbal cues lead you to respond question accurately?

The adult learner stated that teacher's verbal cues were helpful to lead her accuracy. The extract below proves it.

Extract 51

$\mathrm{T} \quad$ : Secara keseluruhan bu isyarat isyarat guru bisa menuntun bahasa Inggris ta?

(Generally, did the teacher's verbal cues lead your accurate English?)

L : Iyasangat, karena isyarat itu bisa membantu mengingat lagi pelajaran yang sudah dipelajari, apalagi inikan lewat telepon biasa mendadak, biasa sementara dijalan tidak pegang buku, kamus. Jadis angat membantu. (Yes, because the cues helped me to remember the lesson, moreover usually it was sudden, I was on the way without book, dictionary. So it was very helpful)

Adult Learner, May 19, 2016

So far, the researcher was satisfied with the findings since the researcher found some kinds of cues to lead the learner's accuracy. But unfortunately, with the deeper investigation, these cues are viewed as temporary monitor. In other words, they could be stored in learner's short term memory only. It was proved by the teacher who frequently cued the same error.

\section{Extract 53}

$\mathrm{T}$ : Yang ditambah 's'dibelakang. Masih ingat? (It is added 's' behind the verb, Do you still remember?)

$\mathrm{L} \quad$ : Oh, she 's'

$\mathrm{T}$ : 'She', Jadi 'live' nyaditambah 's'dibelakang ('She', so 'live' is added by ' $s$ ')

L : Oh yes yes, I remember.

$\mathrm{T}$ : Okay.

L : She lives.

Adult Learner, Grammar, $1^{\text {st }}$ Calling, April 25, 2016

\section{Extract 54}

$\mathrm{T}$ : Ingat, lagilagi.

L : Oh yaya, tambah 's'?

$\mathrm{T}$ : Yes. tambah 's'

L : He works?

$\mathrm{T}$ : Yes. He works 
Based on the extracts above, the adult learner's inaccurate response occurred to grammar which is subject-verb agreement error. It is spotted that the teacher cued the same error in the first calling and the second calling. It indicates that the teacher's verbal cue delivered in the first calling could not become self-correction for adult learner since the teacher still cued the same error in the second calling.

\section{CONCLUSION AND SUGGESTIONS}

Based on the findings and discussion in the previous point, the researcher concluded that (a) verbal indirect cue and verbal direct cue encompassing some kinds of cues were the typically successful verbal cues used by the teacher to lead the adult beginner learner's accuracy and (b) the teacher's verbal cues could facilitate the learner to respond the teacher's questions accurately since the teacher and learner were involved in interpersonal communication.

Considering the conclusions, the researcher gives suggestions as follows: (1) the teacher should trigger the learners to response accurately rather than telling the answer directly, (2) teaching in calling interaction emerges intimacy and friendliness between teacher and learner because this interaction involves interpersonal communication, therefore the teacher should use more interpersonal communication to facilitate the learner achieve the lesson objectives easily, and (3) the teacher's verbal cues found in this research are viewed as temporary monitor, so that the researcher expects the further researchers to find the teacher's verbal cues that can become permanent monitor or self-correction for learners in order that teacher does not need to cue the same error and learners can become independent learners.

\section{REFERENCES}

Henkel, Steven A. 2002. Instructional Cues. PE Central: Activity Cues. Retrieved on February 28th, 2016 from http://people.bethel.edu/ shenkel/TeachingMethods/CueInfo/Cues.html

Jones, Byron. 2007. TEFL Teaching EFL to Beginners: Initial Approaches \& Techniques. Retrieved on February 29th, 2016 from International TEFL and TESOL Training web: https://www.teflcorp.com/articles/86-tefl-teachingbeginner-students/269-teaching-efl-to-beginners-initial-approaches-a-techniques/

Northwestern Illinois Association. ___ Hierarchy of Cueing and Prompting. Retrieved on February 28th, 2016 from http://www.sased.org/vimages/shared/vnews/stories/517e86c8a793d/Cueing\%20 and\%20Prompting.pdf

Rasyid, Muhammad Amin. 2015. Interpersonal Communication $1^{\text {st }}$ edition. Makassar: State University of Makassar Press. 